\author{
JERZY ŁAZOR \\ https://orcid.org/0000-0002-8880-1085 \\ Szkoła Główna Handlowa w Warszawie
}

\title{
PIERWSZA FRANCUSKO-POLSKA KONCESJA KOLEJOWA Z 1924 ROKU. PRZYCZYNEK DO RELACJI FINANSOWO-GOSPODARCZYCH POLSKI I FRANCJI PO I WOJNIE ŚWIATOWEJ*
}

\begin{abstract}
Abstrakt: Francja była głównym sojusznikiem Drugiej Rzeczypospolitej, a zarazem kluczowym dla niej źródłem kapitału. Różnica sił między obydwoma krajami i francuskie inwestycje w polski sektor surowcowy i infrastrukturę powodowały imperialistyczne interpretacje wzajemnych stosunków gospodarczych w obydwu historiografiach. W tekście analizuję historię koncesji kolejowej, udzielonej w 1924 r. polsko-francuskiemu konsorcjum przez władze w Warszawie. Pokazuję, że nawet w ramach asymetrycznych relacji między krajami słabsza strona miała manewr negocjacyjny, a powodzenie przedsięwzięć francuskich firm niekiedy zależało od decyzji Warszawy.
\end{abstract}

Słowa kluczowe: koncesje kolejowe, dyplomacja gospodarcza, imperializm, Polska, Francja, okres międzywojenny.
Abstract: France was the main ally of the Second Polish Republic and, at the same time, its key source of capital. The power difference between the two countries and France's raw materials and infrastructure investments in Poland gave rise to imperialist interpretations of Polish-French economic relations. In this text, I analyse the history of a railway concession granted in 1924 to a Polish-French consortium by the government in Warsaw. I show that even within the asymmetrical context of Polish-French relations, the weaker side had room for manoeuvre during the negotiations. On occasion, the success of the ventures of French companies' depended on decisions taken in Warsaw.

Keywords: railway concessions, economic diplomacy, imperialism, Poland, France, interwar period.

* Artykuł powstał w wyniku realizacji projektu badawczego nr 2018/31/D/HS3/00405 pt. „Ekonomia polityczna francuskiego kapitału w międzywojennej Polsce”, finansowanego ze środków Narodowego Centrum Nauki. Serdecznie dziękuję Dawidowi Kellerowi i Jackowi Luszniewiczowi oraz anonimowym recenzentom za cenne uwagi do tekstu. 


\section{Wstęp}

W 1924 r. konsorcjum polsko-francuskie uzyskało koncesję na budowę i eksploatację sieci kolejowej obejmującej linie łączące Górny śląsk z północną częścią kraju - zapowiedź przyszłej magistrali węglowej. Decyzja ta obudziła nadzieje na szybką rozbudowę infrastruktury kolejowej Drugiej Rzeczypospolitej ${ }^{1}$. W skład konsorcjum, obok poznańskiej firmy budowlanej „Tri” Towarzystwo Robót Inżynierskich i polskich inżynierów, weszły dwa wielkie przedsiębiorstwa francuskie: Schneider et Compagnie i Société Générale d'Entreprises. Po serii konfliktów między Warszawą a Paryżem koncesja została jednak anulowana w 1928 r. Dalsza budowa magistrali przebiegała już na innych zasadach, od 1931 r. w oparciu o druga koncesję, tym razem udzieloną paryskiej spółce Compagnie Franco-Polonaise de Chemins de Fer (Francusko-Polskie Towarzystwo Kolejowe), w której 7/15 udziałów miały Polskie Koleje Państwowe², 8/15 zaś różne podmioty francuskie, w tym wspomniane wyżej dwa przedsiębiorstwa ${ }^{3}$.

Losy pierwszej koncesji są w zasadzie nieznane w literaturze - jej opisy składają się z informacji przedstawionych $\mathrm{w}$ powyższym akapicie wraz z interpretacją, że wycofanie się Polaków z koncesji (zazwyczaj niepoprawnie datowane) było efektem niemożności pozyskania przez koncesjonariuszy finansowania ${ }^{4}$. Moim celem w niniejszym tekście jest zbadanie, co w istocie stało się z koncesją: kiedy i dlaczego została cofnięta. Ciekawi mnie rola państwa francuskiego w rozmowach i występowanie nacisków politycznych, typowych dla międzywojennych relacji polsko-francuskich. Ponieważ ekspansja Francji w Polsce przedstawiana jest jako efekt współdziałania państwa i przedsiębiorstw prywatnych, patrzę też na interakcje tych sfer.

W tekście rekonstruuję nieznaną dotąd w literaturze faktografię koncesji (w tym poprawną chronologię), a następnie, w oparciu o analizę dynamiki negocjacji między koncesjonariuszami a polskimi władzami, daję jej nową interpretację. Wskazuję, że do sukcesów ważnych

${ }^{1}$ W. Jakubowski, Pierwsza wielka koncesja kolejowa w Polsce, „Inżynier Kolejowy” 2, 1925, 4(8), s. 77-80.

${ }^{2}$ Kapitat państwowy w spótkach prawa handlowego u schyłku Drugiej Rzeczypospolitej. Szczegółowe sprawozdanie z działalności przedsiębiorstw o kapitale mieszanym za rok 1937 wzgl. 1937/1938, red. J. Gołębiowski, Kraków 2004, s. 180.

3 „Compagnie Franco-Polonaise de Chemins de Fer”, 1 VI 1934, Archives Diplomatiques (La Courneuve, dalej: AD), Correspondance politique et commercial, 1918-1940, Pologne (dalej: CPC PL 1918-1940), 409, k. 131-134.

${ }^{4}$ Tak np. M. Widernik, Magistrala węglowa Śląsk-Gdynia i jej znaczenie w okresie międzywojennym, ZH 49, 1984, 2, s. 36. 
francuskich inwestycji w Polsce konieczna była dobra wola rządów obydwu krajów. W długotrwałym konflikcie wokół pierwszej koncesji rolę odegrały tak niechęć do angażowania się Paryża, jak i forsowna polityka prowadzona wobec koncesjonariuszy po zamachu majowym. Wielkie firmy francuskie, pozbawione poparcia Ministerstwa Finansów oraz rynku paryskiego, okazały się słabsze od polskiego rządu, który nie tylko dominował w negocjacjach, lecz ostatecznie ich wynik zignorował. Podważa to proste przedstawianie obecności kapitału francuskiego w Polsce jako kontroli sprawowanej przez ,anonimowych władców” ${ }^{5}$ czy też formy imperializmu gospodarczego ${ }^{6}$.

Historiografia omawianego tematu jest ograniczona. Dwie najważniejsze prace, francuskie doktoraty Mylène Mihout-Natar i Christophera Laforesta, nie zostały opublikowane i opisują zagadnienie pobieżnie, bez zagłębiania się w analizę negocjacji. Ich autorzy patrzą też na inwestycje w Polsce ze ściśle francuskiego punktu widzenia ${ }^{7}$. Polska historiografia skupia się na drugiej koncesji na budowę magistrali. Ważną pracę na ten temat napisał Mieczysław Widernik ${ }^{8}$, najobszerniejszą pozycją pozostaje zaś książka Grzegorza Kotlarza, Henryka Dąbrowskiego i Edwarda Wieczorka9

Dla odpowiedzi na postawione w niniejszym artykule pytania ważne znaczenie ma dorobek Zbigniewa Landaua, zwłaszcza badania poświęcone roli kapitału zagranicznego w Polsce ${ }^{10}$. $\mathrm{Z}$ kolei zagraniczny kontekst francuskich starań opisują opracowania o tzw. francuskim sektorze robót publicznych we Francji. Firmy do niego należące specjalizowały się w tworzeniu infrastruktury, często na podstawie zagranicznych koncesji. Najważniejszą pracą jest tu synteza Dominique'a Barjota ${ }^{11}, \mathrm{w}$ badaniu

${ }^{5}$ Z. Landau, J. Tomaszewski, Anonimowi władcy. Z dziejów kapitału obcego w Polsce (1918-1939), Warszawa 1968.

${ }^{6}$ G.-H. Soutou, L'impérialisme du pauvre. La politique économique du gouvernement français en Europe Centrale et Orientale de 1918 à 1929. Essai d'interprétation, „Relations internationales" 3, 1976, 7, s. 219-239.

7 M. Mihout-Natar, „L'intervention des capitaux français dans la Pologne de la Seconde République (1918-1939). Contribution à l'histoire de l'impérialisme économique français en Europe centrale”, praca doktorska obroniona w Université Charles de Gaulle - Lille III, Lille 2002, s. 740-745; Ch. Laforest, „La stratégie française et la Pologne (1919-1939). Aspects économiques et implications politiques", praca doktorska obroniona w Université Paris 1 Panthéon-Sorbonne, Paris 2001, s. 177-183.

${ }^{8}$ M. Widernik, op. cit.

${ }^{9}$ G. Kotlarz, H. Dąbrowski, E. Wieczorek, Magistrala węglowa. Najciekawsze linie kolejowe Polski, Rybnik 2017.

10 Z. Landau, Polskie zagraniczne pożyczki państwowe 1918-1926, Warszawa 1961; idem, Plan stabilizacyjny 1927-1930. Geneza, założenia, wyniki, Warszawa 1963.

${ }^{11}$ D. Barjot, La grande entreprise française de travaux publics (1883-1974), Paris 2006. 
sytuacji w Polsce przydatne są też opracowania szczegółowe Anne Burnel $^{12}$ i Agnès D’Angio ${ }^{13}$. O historiografii kapitału francuskiego w międzywojennej Polsce piszę w odrębnym tekście ${ }^{14}$.

Główne źródła opisujące przebieg negocjacji znajdują się we francuskich Archives Diplomatiques w La Courneuve, gdzie zachowała się korespondencja prowadzona przez paryskie Ministerstwo Spraw Zagranicznych (Ministère des Affaires Étrangères, MAÉ) i przedstawicieli dyplomatycznych w Warszawie. Niestety, w najważniejszej jednostce archiwalnej, zawierającej dokumenty na temat koncesji, brakuje materiałów z 1926 r. $^{15}$, co utrudnia precyzyjne odtworzenie kolejnych etapów rozmów. W materiałach francuskiego Ministerstwa Finansów (Ministère des Finances, MF) odnalazłem jedynie dokumenty na temat drugiej koncesji ${ }^{16}$.

W polskim Archiwum Akt Nowych, w archiwaliach prowadzącego negocjacje z Francuzami Ministerstwa Komunikacji w Warszawie (do 1924 r. - Ministerstwa Kolei Żelaznych, następnie między 1924 a 1926 r. Ministerstwa Kolei) nie zachowały się materiały na temat pierwszej koncesji. Analogicznie, brak informacji na jej temat w zespole Ambasady Rzeczypospolitej Polskiej w Paryżu (co nie dziwi, skoro negocjacje prowadzono w większości w Polsce). W spuściźnie Ministerstwa Spraw Zagranicznych (MSZ) znaleźć można jedynie dokumenty na temat budowy linii w latach trzydziestych ${ }^{17}$.

Stan źródeł narzuca szczególny rygor ich krytyki. Podstawą niniejszego tekstu są w większości pisma i wewnętrzne notatki autorstwa pracowników MAÉ. Niekiedy zachowały się odpowiedzi Polaków, czasem znam je jedynie z omówień. Negocjacje z warszawskim Ministerstwem Komunikacji prowadziły prywatne firmy francuskie, a badane dokumenty powstały w urzędach centralnych, do których przedsiębiorstwa te zwracały się z prośbą o pomoc. W konsekwencji, francuscy dyplomaci dysponowali jedynie częściową wiedzą na omawiane tematy, przefiltrowaną przez interes prywatnych negocjatorów. Widać to chociażby na

12 A. Burnel, La société de construction des Batignolles de 1914 à 1939. Histoire d'un déclin, Genève 1995.

13 A. D'Angio, Schneider et Cie et la naissance de l'ingénierie. Des pratiques internes à l'aventure internationale 1836-1949, Paris 2000.

${ }^{14} \mathrm{~J}$. Łazor, Kapitał francuski $w$ Polsce międzywojennej. Stan badań i postulaty badawcze, „UR Journal of Humanities and Social Sciences” 4, 2019, 1(10), s. 29-52.

15 AD, CPC PL 1918-1940, 263.

16 Centre des Archives Économiques et Financières (Savigny-le-Temple), Direction du Trésor. Relations internationales - Pologne 1919-1939, B 31.946.

17 AAN, Ministerstwo Spraw Zagranicznych w Warszawie (dalej: MSZ), 3851 i 3853. 
początku 1928 r., kiedy poseł Jules Laroche dopiero w trakcie interwencji dyplomatycznej dowiedział się, że reprezentanci koncesjonariuszy nie stawili się na rozmowy z Polakami ${ }^{18}$. Do dokumentów francuskich podchodzę zatem szczególnie ostrożnie, choć z powodu braku konkurencyjnej polskiej narracji trudno mi podważyć zawarte w nich stwierdzenia.

Tekst składa się z trzech części. W pierwszej analizuję negocjacje prowadzące do podpisania koncesji i jej konstrukcję; w drugiej - kolejne etapy konfliktu wokółbudowy kolei, których ostatecznym efektem było faktyczne anulowanie koncesji; w trzeciej zastanawiam się nad uczestnikami negocjacji, przyjętymi przez nich strategiami negocjacyjnymi i interakcjami między instytucjami państwowymi a sferą prywatną. Łącznie pozwala mi to odpowiedzieć na pytanie o przyczyny niepowodzenia rozmów.

\section{Nadanie koncesji}

W 1923 r. polskie władze przedstawiły program rozbudowy sieci kolejowej, którego elementem była linia łącząca polską część Górnego śląska $\mathrm{z}$ resztą kraju ${ }^{19}$. Był to element szerszej polityki kolejowej, mającej przede wszystkim na celu zniwelowanie zniszczeń wojennych, poza tym zaś integrację transportową nowego państwa. $\mathrm{W}$ tej wizji połączenie bogatego i uprzemysłowionego Górnego Śląska z ziemiami dawnych zaborów oraz z bałtyckimi portami było jednym z priorytetów ${ }^{20}$.

Poznańska firma budowlana „Tri” Towarzystwo Robót Inżynierskich zwróciła się do dwóch firm francuskich, Société Générale d’Entreprises i Schneider et Compagnie, z propozycją współpracy w uzyskaniu koncesji na budowę wspomnianej linii z Górnego Śląska. Po przeprowadzeniu wstępnych badań, 12 grudnia 1923 r., Francuzi zgodzili się połączyć siły $\mathrm{z}$ Tri ${ }^{21}$. Polska spółka miała w tym układzie grać głównie rolę pośrednika w pozyskaniu kapitału zagranicznego. Polskie władze proponowały grupie podpisanie wstępnego porozumienia, w którym ustalono by wymogi techniczne konstrukcji i okres dalszej eksploatacji przez budowniczych

18 J. Laroche do A. Brianda, 28 II 1928, AD, CPC PL 1918-1940, 263, k. 219-220v.

19 „Note concernant les nouvelles lignes de chemins de fer en Pologne”, 18 IV 1924, AD, CPC PL 1918-1940, 263, k. 97-100.

${ }^{20}$ Por. G. Kotlarz, H. Dąbrowski, E. Wieczorek, op. cit., s. 10-11; Z. Landau, J. Tomaszewski, Gospodarka Polski międzywojennej 1918-1939, t. 1: W dobie inflacji 1918-1923, Warszawa 1967, s. 225-228.

${ }^{21}$ „Note sur la concession de chemins de fer en Pologne dits «Chemins de fer houliers»", 10 VI 1927, AD, CPC PL 1918-1940, 263, k. 186; Nota werbalna Ambasady Francuskiej w Warszawie (dalej: AFW) do MSZ, 23 VI 1927, ibidem, k. 198. 
(początkowo mówiono o 80 latach), a jednocześnie zagwarantowano by określony poziom zwrotu z inwestycji ${ }^{22}$.

Głównym problemem firm starających się o koncesję było pozyskanie odpowiednich funduszy. Budowę planowano finansować emisją pożyczki na rynku francuskim, przewidując wstępnie pięć transz emitowanych w rocznych odstępach, o łącznej wartości miliarda franków. Francuskie firmy zwróciły się o poparcie do paryskiego rządu, prosząc z jednej strony o pomoc w kontaktach $\mathrm{z}$ francuskim sektorem finansowym, $\mathrm{z}$ drugiej zaś szukając oparcia w negocjacjach z władzami polskimi. Większe ustępstwa Warszawy mogły uspokoić inwestorów w Paryżu i w konsekwencji zapewnić łatwiejszy dostęp do kredytu. Aby przekonać rząd, francuscy przedsiębiorcy określili projekt jako bardzo istotny, dodając, że zapewni on „krajowi, któremu powierzone zostaną te przedsięwzięcia [- - dominującą pozycję w Polsce"23.

Rząd francuski żywo śledził zmiany w polskim transporcie i zaangażowanie weń kapitału zagranicznego. W kwietniu 1924 r. nowy projekt pozyskał zainteresowanie premiera i ministra spraw zagranicznych Raymonda Poincarégo. Ten widział w nim część szerszego pakietu projektów, które miały ułatwić utrzymanie wpływów francuskich w Polsce, wynikających z sojuszu wojskowego oraz francuskich pożyczek i inwestycji z pierwszej połowy lat dwudziestych. Nowe przedsięwzięcia, do których należała też budowa portu w Gdyni, miały również na celu wzmocnienie francuskiego sojusznika ${ }^{24}$.

Poincaré chętnie polecił francuskiemu posłowi w Warszawie wsparcie firm w negocjacjach, choć niepokoiły go kwestie finansowe. Ówczesna sytuacja gospodarcza Francji nie była dobra. Aby chronić rynek wewnętrzny, władze kontrolowały eksport kapitału, co już na wstępie uzależniało powodzenie projektów w rodzaju pożyczki od stanowiska Ministerstwa Finansów. Co gorsza inwestorzy, po doświadczeniu utraty rynku rosyjskiego i po latach wojny, również nabrali ostrożności. Zaangażowanie kapitału w Polsce, której przyszłość postrzegano jako niepewną, jawiło się jako szczególnie niebezpieczne, stąd trudno było liczyć na pozyskanie finansowania przyszłej koncesji bez udziału francuskich

22 „Note concernant les nouvelles lignes de chemins de fer en Pologne”, 18 IV 1924, AD, CPC PL 1918-1940, 263, k. 93.

23 Ibidem, k. 94.

${ }^{24}$ R. Poincaré do F. François-Marsala, 28 IV 1924, AD, CPC PL 1918-1940, 263, k. 101v.; Z. Landau, Polskie zagraniczne pożyczki, s. 199; C. Laforest, La stratégie française et la Pologne (1919-1939). Aspects économiques et implications politiques, „Histoire, économie et société" 22, 2003, 3, s. 395-411; J. Łazor, Kto ma budować Gdynię? Wpływ władz w Paryżu na kształt konsorcjum francusko-polskiego, „Dzieje Najnowsze” [w druku]. 
władz. Poincaré miał na uwadze podpisanie kilka tygodni wcześniej, w marcu 1924 r., umów regulujących pożyczkę tytoniową, która dała włoskiemu Banca Commerciale Italiana kontrolę nad sektorem tytoniowym w Polsce. O kontrakt ten starała się również francuska spółka Société Anonyme des Tabacs d'Orient \& d'Outre-Mer ${ }^{25}$. W liście do ministra finansów Frédérica François-Marsala Poincaré przypominał ${ }^{26}$, że Włosi zawdzięczali wygraną, „wyjątkowo przykrą tak dla grupy francuskiej, jak i dla francuskiego rządu"27, m.in. poparciu Rzymu. Analogicznie, w kwietniu 1924 r. Société Française des Bois Coloniaux przegrało rywalizację z Anglikami (The Century European Corporation) o koncesję na eksploatację Puszczy Białowieskiej. Poincaré dowodził, że brak gwarancji francuskich władz podkopywał także możliwość uzyskania kontraktu w Gdyni oraz dzierżawy w Drohobyczu i obawiał się, że problem ten dotknie również sprawy kolei. Ponieważ w tym samym czasie francuskie inwestycje napotykały na podobne trudności w Królestwie Serbów, Chorwatów i Słoweńców, premier pytał się swojego ministra finansów, czy „rząd, jakiekolwiek nie były jego trudności finansowe, nie miałby wyższego interesu politycznego, aby zgodzić się w pewnym stopniu na eksport kapitałów do krajów, które stanowią część naszego systemu politycznego" ${ }^{28}$. Mimo ponawianych próśb premiera, François-Marsal sprzeciwił się jednak dopuszczeniu interwencji państwa na rynku finansowym i odmówił angażowania się w pożyczkę na budowę polskiej kolei ${ }^{29}$. Choć rząd Poincarégo wkrótce upadł, a po efemerycznym gabinecie samego François-Marsala w czerwcu 1924 r. władzę przejął Kartel Lewicy, decyzja ta nie została zmieniona. Co więcej, po tej rewolucji gabinetowej w Paryżu stosunki polsko-francuskie ochłodziły się. Stan ten pogłębiły traktaty lokarneńskie, a następnie zamach majowy ${ }^{30}$.

25 Société Anonyme des Tabacs d'Orient \& d'Outre-Mer do R. Poicaré, 30 V 1923, AD, CPC PL 1918-1940, 275, k. 182. O udziale Francuzów w negocjacjach milczy Zbigniew Landau (Polskie zagraniczne pożyczki, s. 209-234).

${ }^{26}$ R. Poincaré do F. François-Marsala, 30 V 1924, AD, CPC PL 1918-1940, 263, k. 108v.

27 „Politique de la France en Pologne et en Serbie”, 15 V 1924, AD, CPC PL 19181940, 231, k. 36.

${ }^{28}$ R. Poincaré do F. François-Marsala, 30 V 1924, AD, CPC PL 1918-1940, 263, k. 108v.

${ }^{29}$ F. François-Marsal do R. Poincarégo, 2 VI 1924, AD, CPC PL 1918-1940, 263, k. 111-111v.; Dwie minuty pism R. Poincarégo do F. François-Marsala, 7 VI 1924, ibidem, k. $115-116 \mathrm{v}$.

${ }^{30}$ G.-H. Soutou, L'Alliance franco-polonaise (1925-1933) ou comment s'en débarrasser, "Revue d'histoire diplomatique” 1981, 2, 3, 4, s. 295-348; P.S. Wandycz, The Twilight of French Eastern Alliances, 1926-1936. French-Czechoslovak-Polish Relations from Locarno to the Remilitarization of the Rhineland, Princeton 1988, s. 121; H. Bułhak, Polska - Francja. Z dziejów sojuszu 1922-1939, cz. 1: 1922-1932, Warszawa 1993, s. 227-291. 
Mimo niepełnego wsparcia Paryża, francuskie firmy przystąpiły do negocjacji z rządem Władysława Grabskiego. Według ich głównego przedstawiciela, Ernesta Weyla, polski premier był ,jawnie wrogi” wobec projektu, podobnie jak wobec pożyczki na budowę Gdyni. Argumentował, że „każda prośba o francuską pomoc finansową jest z góry skazana na porażkę", raz z powodu sytuacji francuskich finansów, dwa - ze względu na zakaz eksportu kapitału ${ }^{31}$. Z przychylniejszym nastawieniem francuscy negocjatorzy spotkali się w trakcie rozmów z ministrem kolei żelaznych Kazimierzem Tyszką. Postawa Grabskiego (później zwłaszcza zrezygnowanie przez Polskę z czwartej transzy pożyczki wojskowej ${ }^{32}$ ) wywołała w Paryżu zaniepokojenie. Odbierano ją jako sygnał, że polski rząd, niebędący pod presją uzyskania od Francji pieniędzy, zdobędzie rosnącą niezależność od swego sojusznika ${ }^{33}$.

W tej sytuacji francuskie firmy zadowoliły się jedynie zgodą na badania techniczne planowanej linii ${ }^{34}$. Rozwiązanie to było rozczarowujące, gdyż zgodnie z art. 5 ustawy o koncesjach kolejowych z 1921 r., „zezwolenie na studia przedwstępne [--] nie przesądza o wydaniu samej koncesji" 35 . Wyniki prac rozpoczętych wiosną 1924 r. przekazano Polakom rok później.

Sytuacja zaczęła się polepszać w połowie roku. Najpierw negocjujące na własną rękę Tri 6 maja 1924 r. podpisało z Ministerstwem Kolei Żelaznych porozumienie regulujące zasady przyszłej koncesji ${ }^{36}$. Francuskie firmy zgodziły się na jego zapisy 11 listopada 1924 r. Dla późniejszych negocjacji istotne były dwa zapisy dotyczące kwestii finansowych. Artykuł 12 gwarantował starającym się o koncesję zwrot poniesionych na wstępne studia kosztów, jeśli z jakichś przyczyn konstrukcja nie doszłaby do skutku ${ }^{37}$. Co ważniejsze, zgodnie z art. 15 Ministerstwo Kolei Żelaznych zobowiązało się wystąpić do polskiego parlamentu o udzielenie gwarancji finansowej inwestycji ${ }^{38}$. Do kwestii tych wrócę niżej.

31 „Construction de nouvelles voies ferrées en Pologne”, 6 VI 1924, AD, CPC PL 1918-1940, 263, k. 114.

32 C. Laforest, Kulisy zrzeczenia się przez Polskę czwartej raty pożyczki francuskiej w 1925 r., „Dzieje Najnowsze” 31, 1999, 3, s. 91-99.

33 „Note sur le projet de construction de nouvelles voies ferrés en Pologne”, $13 \mathrm{~V}$ 1925, AD, CPC PL 1918-1940, 263, k. 158-159.

34 „Construction de nouvelles voies ferrées en Pologne”, 6 VI 1924, AD, CPC PL 1918-1940, 263, k. 114v.

35 Ustawa z dnia 14 października 1921 r. o udzieleniu koncesji na koleje żelazne prywatne, Dz. U. 1921, nr 88, poz. 646.

${ }^{36}$ Nie udało mi się odnaleźć treści porozumienia. Niektóre jej zapisy znam jedynie z późniejszych omówień.

37 Nota werbalna MSZ do AFW, 26 VIII 1927, AD, CPC PL 1918-1940, 263, k. 195-196.

38 „Note sur la concession de chemins de fer en Pologne dits «Chemins de fer houillers»", 10 VI 1927, AD, CPC PL 1918-1940, 263, k. 189. 
Tak zabezpieczeni, przedstawiciele firm francuskich wspólnie z reprezentantami Tri wystąpili formalnie o koncesję ${ }^{39}$. Została im ona przyznana na mocy zarządzenia prezydenta z 15 grudnia 1924 r. ${ }^{40}$ Zgodnie z jej zapisami Tri (z wymienionymi z nazwiska jego kierownikiem, profesorem Olechem Stelmachowskim, a także inżynierami Władysławem Jakubowskim i Bolesławem Walkiewiczem), Schneider et $C^{\text {ie }}$ oraz Société Générale d'Entreprises uzyskały koncesję na budowę pięciu linii kolejowych ${ }^{41}$, które wspólnie łączyć miały polskie zagłębia z Warszawą i północną częścią kraju, a zarazem umożliwić ominięcie terytorium niemieckiego. Najważniejszą z nich była linia Kalety-Wieluń-Inowrocław z odnogą Wieluń-Podzamcze.

Jak w „Inżynierze Kolejowym” pisał jeden z koncesjonariuszy, Władysław Jakubowski, całokształt koncesji miał składać się z „czterech dokumentów: już wydanego zarządzenia koncesyjnego [--], ustawy gwarancyjnej, uchwalonej przez Sejm, Statutu Towarzystwa i na koniec dokumentu koncesyjnego, zawierającego szczegółowe skodyfikowanie praw i zobowiązań Towarzystwa budowy i eksploatacji koncesjonowanych kolei" ${ }^{2}$. Stwierdzenie to wymaga komentarza, gdyż wokół tych dokumentów przez najbliższe trzy lata narastały spory (i ostatecznie żaden poza zarządzeniem koncesyjnym nie został opublikowany).

Zarządzenie koncesyjne było skromne w treści. Ograniczało się do wymienienia koncesjonariuszy, określenia ogólnie tras, które miały zostać wybudowane oraz wyznaczenia okresu budowy i późniejszej eksploatacji na 81 lat. Definiowało poza tym prawa, którymi dysponowali koncesjonariusze: do wywłaszczania przymusowego nieruchomości pod budowę kolei oraz do utworzenia spółki akcyjnej w celu realizacji budowy i eksploatacji linii (nazywanej niekiedy Towarzystwem Śląsko-Warszawsko-Bałtyckich Kolei). Zarządzenie określało przy tym (§ 4), że statut tej spółki, wspomniany przez Jakubowskiego, ,winien odpowiadać warunkom finansowania, zarządu i likwidacji powstającego przedsiębiorstwa, zastrzeżonym w dokumencie koncesyjnym".

Dokument koncesyjny miał zostać wydany przez ministra kolei, a koncesjonariusze mieli być związani jego zapisami. Był on zapewne

39 Ibidem, k. 186.

${ }^{40}$ Zarzadzenie Prezydenta Rzeczypospolitej z dnia 15 grudnia 1924 r. w sprawie udzielenia koncesji na budowę i eksploatację kolei żelaznych prywatnych użytku publicznego z Zagłębia Węglowego Dąbrowskiego i Śląskiego do Inowrocławia, Łaska-Brodnicy i Warszawy, Dz. U. 1924, nr 110, poz. 988.

41 1) Kalety-Herby-Wieluń-Opatówek/Błaszki-Inowrocław, z odnogą WieluńPodzamcze/Halunin; 2) Chorzów-Wojkowice-Łask wraz z odnogami; 3) CiechomicePłock-Brodnica; 4) Wojkowice-Opoczno-Warszawa wraz z przyłączami; 5) południowa wewnętrzna obwodowa linia kolejowa węzła warszawskiego.

${ }^{42}$ W. Jakubowski, Pierwsza wielka koncesja, s. 77. 
tożsamy ze zdefiniowanym $\mathrm{w}$ art. 8 wspomnianej ustawy o koncesjach ${ }^{43}$ "planem generalnym" i nazywany we francuskiej korespondencji cahier des charges. W korespondencji sprzed wydania koncesji - Francuzi powoływali się tu na list z 20 listopada 1924 r. - stwierdzono, że dokument ten zostanie przygotowany $\mathrm{w}$ porozumieniu $\mathrm{z}$ koncesjonariuszami ${ }^{44}$. $\mathrm{Z}$ rozporządzenia wykonawczego do ustawy o koncesjach wynikał obowiązek opublikowania dokumentu koncesyjnego na koszt koncesjonariusza w „Monitorze Polskim”45.

Możliwość rozpoczęcia budowy uzależniona była od emisji pożyczki na rynku francuskim, a jak w czasie negocjacji z Ministerstwem Kolei mówili Francuzi, ta z kolei zależała od tego, czy Polacy zagwarantują odpowiedni zwrot z inwestycji. W praktyce oznaczało to konieczność udzielenia przez władze Drugiej Rzeczypospolitej formalnej gwarancji, że w przypadku nieosiągnięcia przez koncesjonariuszy zysku o określonej wysokości, to państwo polskie dopłaci konieczną w danym roku kwotę. Tego typu zapisy wiązały się zazwyczaj z określeniem zastawu, który miał w razie czego służyć realizacji gwarancji. Ponieważ ustawa o koncesjach regulowała w art. 4, że „pomoc ekonomiczna” ze Skarbu Państwa mogła zostać przyznana koncesjonariuszom jedynie w drodze ustawodawczej, gwarancja, będąca formą takiej pomocy, wymagała uchwalenia przez sejm odpowiedniej ustawy. W trakcie negocjacji prowadzących do udzielenia koncesji zdecydowano się na wspomniane pośrednie rozwiązanie, zgodnie z którym Ministerstwo Kolei Żelaznych zobowiązało się wystąpić do parlamentu o udzielenie odpowiedniej gwarancji ${ }^{46}$.

\section{Zmiana koncesji i jej faktyczne anulowanie}

Problemy z realizacją koncesji sprowadzić można do trzech powiązanych zagadnień: przyspieszonej budowy części linii nią objętych, przyjęcia przez Polaków nowej koncepcji linii, wreszcie prób pozbycia się

43 Ustawa z dnia 14 października 1921 r. o udzieleniu koncesji na koleje żelazne prywatne, Dz. U. 1921, nr 88, poz. 646.

${ }^{44}$ Concession des Chemins de Fer Silésie-Varsovie-Baltique, Direction des Études de la Ligne Wieluń-Inowrocław do J. Laroche’a, 14 III 1928, AD, CPC PL 1918-1940, 263, k. 232.

45 Rozporzadzenie Ministra Kolei Żelaznych z dnia 30 września 1922 r. w przedmiocie wykonania ustawy z dnia 14 października roku 1921 o udzielaniu koncesji na koleje żelazne prywatne, Dz. U. 1922, nr 92, poz. 854.

${ }^{46}$ „Note sur la concession de chemins de fer en Pologne dits «Chemins de fer houillers»", 10 VI 1927, AD, CPC PL 1918-1940, 263, k. 189. 
przez nich zobowiązań wobec Francuzów. Za nimi z kolei stał podwójny problem: trudności z pozyskaniem finansowania przez francuskie firmy, a jednocześnie ociąganie się polskich władz z udzieleniem im gwarancji.

W 1925 r. Polacy zdecydowali się własnymi środkami wybudować trasę Kalety-Herby-Wieluń-Podzamcze, bez czekania na zdobycie finansowania przez firmy francuskie. Linia ta umożliwiała transportom z Górnego Śląska ominięcie terytorium Niemiec. Budowa była możliwa dzięki prowadzonym na przełomie 1924 i 1925 r. negocjacjom, które doprowadziły do udzielenia Polsce pożyczki przez amerykański bank Dillon, Read and Co., wyemitowanej ostatecznie 15 lutego $1925 \mathrm{r}^{47}$

Budowa tej trasy, stanowiącej część linii objętych koncesją, była sprzeczna z zarządzeniem prezydenta z grudnia $1924 \mathrm{r}$. Rozpoczęto więc rozmowy z Francuzami, starając się przekonać ich do zgody na zmianę warunków. Ci rozumieli polskie argumenty, bali się jednak precedensu, który mógł w przyszłości podważyć realizację przyznanych im praw. Ostatecznie, ku zadowoleniu Francuzów, problem został uregulowany w ustnej umowie. Konsorcjum polsko-francuskie zrzekło się budowy odcinka Kalety-Podzamcze, który miał zostać wybudowany przez polskie firmy, wskazane rządowi przez konsorcjum. To miało w zamian najpierw otrzymać 10 proc. wartości prac, a w przyszłości, po zakończeniu budowy całości, przekazać polskim władzom koszt budowy wspomnianego odcinka, który wrócić miał następnie, zgodnie z pierwotną umową, do koncesji eksploatacyjnej ${ }^{48}$.

Rozmowy z Francuzami zakończono na początku czerwca 1925 r. Kilka dni później koncepcję za nimi stojącą potwierdziło rozpoczęcie przez Niemcy wojny celnej w Polską ${ }^{49}$, która uczyniła ze sprawnego transportu polskiego węgla pomijającego niemieckie terytorium konieczny warunek obrony krajowej gospodarki. 23 czerwca 1925 r. uchwalono krótką ustawę upoważniającą państwo do podjęcia budowy linii ${ }^{50}$, jazdy próbne na trasie rozpoczęto już pod koniec 1925 r., a pierwszy pociąg z węglem przejechał linią w następnym roku ${ }^{51}$.

Równolegle do regulacji linii Kalety-Podzamcze, odrębna ustawa powierzyła rządowi budowę innej linii kolejowej o długości $190 \mathrm{~km}$,

47 Z. Landau, Polskie zagraniczne pożyczki, s. 234-247.

48 „Projet de construction de nouvelles lignes de chemin de fer en Pologne”, 13 VI 1925, AD, CPC PL 1918-1940, 263, k. 165v.-166.

${ }^{49}$ K.J. Błahut, Polsko-niemieckie stosunki gospodarcze w latach 1919-1939, Wrocław 1975, s. $65-76$.

50 Ustawa z dnia 23 czerwca 1925 r. o budowie kolei Kalety-Herby-Wieluń-Podzamcze, Dz. U. 1925, nr 74, poz. 514.

${ }^{51}$ M. Widernik, op. cit., s. 35. 
która łączyć miała Gdynię z Bydgoszczą. Również ta budowa miała być prowadzona przez Polskę oraz finansowana ze środków budżetowych i pożyczek zagranicznych ${ }^{52}$. Co istotne, projektowany fragment nie był objęty polsko-francuską koncesją. Z uchwaleniem tej ustawy można wiązać przygotowanie Polaków do budowy całej magistrali węglowej, której przebieg południowy nie w pełni pokrywał się z pierwotnym objętym koncesją planem. W nowych założeniach znaczną część trasy przeniesiono z lewego na prawy brzeg Warty. Według Mieczysława Widernika, za decyzją tą stały tak względy gospodarcze, jak i strategiczne: „Nowa trasa przebiegała przez tereny słabiej nasycone siecią kolejową, skracała połączenie Łodzi z magistralą, a przez magistralę ze Śląskiem i portami”"53. Widernik przedstawia plany z lata 1925 r. jako zupełnie odrębne od wcześniejszych i niezwiązane z koncesją dla Francuzów ${ }^{54}$. Stwierdza także, bez powołania się na źródło, że koncesja z 1924 r. została unieważniona $-\mathrm{z}$ kontekstu wynika, że miało to miejsce wkrótce po napotkaniu przez Francuzów na trudności kredytowe ${ }^{55}$. Takiej tezy nie potwierdzają francuskie archiwalia, wskazując tak na przekonanie koncesjonariuszy i francuskich dyplomatów o ciągłości działań z lat 1924-1928, jak i na pewne uznanie tej ciągłości przez Polaków.

Faktycznie ani w lecie 1925 r., ani w następnych miesiącach nie doszło do cofnięcia koncesji. Francuzi wciąż uznawali się za związanych jej zapisami oraz czekali na dokument koncesyjny i wystąpienie przez rząd do parlamentu z wnioskiem o udzielenie koncesjonariuszom gwarancji finansowej. Jednocześnie jednak na rynku francuskim trudno było myśleć o emisji nowej polskiej pożyczki. W listopadzie $1925 \mathrm{r}$. poseł francuski Hector André Panafieu pisał, że z powodu niemożności znalezienia finansowania „trudno przewidzieć, kiedy będzie można zacząć budowę" 56 .

Francuzi starali się pozyskać finansowanie koncesji w USA, Polacy jednak wielokrotnie prosili ich o zaprzestanie tych rozmów, gdyż nie chcieli, aby wpłynęły one na ich własne, polskie starania o pożyczkę w Nowym Yorku ${ }^{57}$. Wynikało to z sytuacji rynkowej - jak pisał Zbigniew

52 Ustawa z dnia 23 czerwca 1925 r. o budowie kolei Bydgoszcz-Gdynia, Dz. U. 1925, nr 74, poz. 513.

${ }^{53}$ M. Widernik, op. cit., s. 37.

${ }^{54}$ Ibidem, s. 36-37.

${ }^{55}$ Podobną tezę stawia Agnès D'Angio (op. cit., s. 211), stwierdzając, że Schneider brał udział w staraniach o budowę linii jedynie w latach 1924-1925.

${ }^{56}$ H.A. Panafieu do A. Brianda, 29 XI 1925, AD, CPC PL 1918-1940, 263, k. 176v.-177.

57 Note „Projet de construction de nouvelles lignes de chemin de fer en Pologne”, 13 VI 1925, AD, CPC PL 1918-1940, 263, k. 166; Concession des Chemins de Fer 
Landau - przy niechęci Banku Anglii „rynek amerykański był w 1926 r. jedynym teoretycznie dostępnym dla Polski rynkiem kredytowym" 58 . Stały za tym również problemy finansowe Francji, która pod rządami Kartelu Lewicy doświadczyła znacznego spadku wartości franka. W lipcu 1926 r. do władzy wrócił Poincaré, który tym razem pozycję premiera połączył z teką ministra finansów. Przeprowadzone przez niego reformy finansowe doprowadziły do ustanowienia nowego franka w $1928 \mathrm{r}^{59}$

Już po powrocie Poincarégo, w listopadzie 1926 r., Polacy poprosili Francuzów o przedstawienie planu finansowego budowy, ci jednak tłumaczyli się, że wobec braku gwarancji trudno sporządzić wiarygodny dokument ${ }^{60}$. Fakt wystąpienia przez polskie władze $z$ taką prośbą dowodzi, że nie traktowały one jeszcze koncesji jako wygasłej. Co więcej, ponieważ Polacy sami mieli trudności finansowe, zaprosili koncesjonariuszy do rozmów na temat przedłużenia linii objętej koncesją aż do Gdyni. Finansowaniem budowy była ponoć zainteresowana amerykańska firma Blair \& Co. Inc., uzależniając jednak włączenie się doń od udzielenia przez Polaków gwarancji ${ }^{61}$. Koncesjonariusze wykonali studia techniczne i finansowe tego projektu, wywiązując się z narzuconego im przez polskie władze terminu 31 maja $1927 \mathrm{r}^{62}$

Równolegle temat budowy kolei do Gdyni podjęła inna firma z sektora robót publicznych we Francji, Société de Construction des Batignolles, kierująca konsorcjum polsko-francuskim prowadzącym roboty w gdyńskim porcie. W marcu 1927 r. jej przedstawiciele zaproponowali rządowi polskiemu budowę linii kolejowych za kwotę $13 \mathrm{mln}$ dolarów, przy czym byli gotowi od razu otworzyć kredyt o wartości 3 mln dolarów. W ocenie Francuzów, ich oferta powinna pozwolić na wybudowanie przeszło połowy planowanej linii do Gdyni. Władze firmy uzależniały zaangażowanie większych środków w Polsce od losów negocjowanej wówczas pożyczki stabilizacyjnej ${ }^{63}$. Gdyby nie udało się jej uzyskać, francuska

Silésie-Varsovie-Baltique, Direction des Études de la Ligne Wieluń-Inowrocław do J. Laroche'a, 14 III 1928, ibidem, k. 233.

58 Z. Landau, Plan stabilizacyjny, s. 101.

${ }^{59}$ K. Mouré, Managing the Franc Poincaré. Economic Understanding and Political Constraint in French Monetary Policy, 1928-1936, Cambridge 1991, s. 12-13.

${ }^{60}$ Concession des Chemins de Fer Silésie-Varsovie-Baltique, Direction des Études de la Ligne Wieluń-Inowrocław do J. Laroche'a, 14 III 1928, AD, CPC PL 1918-1940, 263, k. 232-233.

61 „Note «Concession de chemins de fer en Pologne» pour Monsieur Philippe Berthelot”, 2 II 1928, AD, CPC PL 1918-1940, 263, k. 208.

62 "Note sur la concession de chemins de fer en Pologne dits "Chemins de fer houillers»", 10 VI 1927, AD, CPC PL 1918-1940, 263, k. 188-188v.

${ }^{63}$ Z. Landau, Plan stabilizacyjny. 
firma gotowa była zaproponować własne finansowanie budowy do kwoty nawet $50 \mathrm{mln}$ dolarów ${ }^{64}$.

Koszty francuskiej propozycji były wysokie: 7,5 proc. rocznie z półtorarocznym terminem spłaty. Zabezpieczenie pożyczki stanowić miały ośmioprocentowe obligacje z 1925 r. o wartości 150 proc. kwoty pożyczki ${ }^{65}$. Łączne zatem oprocentowanie wynosiło 19,5 proc., co było wartością porównywalną z pożyczkami zaciągniętymi za czasów Władysława Grabskiego, uznawanymi za niekorzystne ${ }^{66}$. Oferta nie została zaakceptowana ${ }^{67}$.

Przedstawiciele tej samej firmy francuskiej wrócili do rozmów z polskimi władzami po utworzeniu konsorcjum $z$ innymi firmami prowadzącymi działalność w Polsce: Towarzystwem Ulen ${ }^{68}$ oraz bankami: Dillon, Read and Co. i Marshall Field (tzw. konsorcjum Batignolles-Ulen). Budowa linii, będącej częścią większej sieci kolejowej, miała być finansowana emisją nowej pożyczki, której łączną wartość określono na $120 \mathrm{mln}$ dolarów. Tak wysoka kwota, niemal dwukrotnie większa niż w przypadku pożyczki stabilizacyjnej, budziła wątpliwości Jules'a Laroche’a, choć poseł w grudniu 1927 r. uznawał sam pomysł udziału Batignolles w inwestycji za dobry ${ }^{69}$. W marcu 1928 r. pisał jednak, że Polacy liczą na rozgrywanie obydwu grup francuskich przeciwko sobie ${ }^{70}$. Jeszcze w październiku tego roku przedstawiciel Batignolles mówił o możliwości finansowania budowy przez szerokie konsorcjum, w którym uczestniczyłyby też Société Générale i Bank Francusko-Polski (będący faktycznie polskim przedstawicielem Banque de Paris et des Pays Bas). Poproszono więc rząd francuski o zgodę na emisję koniecznej pożyczki na rynku francuskim ${ }^{71}$. Ostatecznie sprawa ta nie przyniosła rezultatów. Anne Burnel, badaczka dziejów

${ }^{64}$ J. Laroche do A. Brianda, 8 IV 1927, AD, CPC PL 1918-1940, 263, k. 181-181v.

65 „Projet de contrat pour la construction et le financement de lignes de chemins de fer en Pologne", AD, CPC PL 1918-1940, 263, k. 182-184v.

66 Z. Landau, Polskie zagraniczne pożyczki, s. 200; Z. Landau, J. Tomaszewski, Gospodarka Polski międzywojennej 1918-1939, t. 2: Od Grabskiego do Piłsudskiego. Okres kryzysu poinflacyjnego i ożywienia koniunktury 1924-1929, Warszawa 1971, s. 227-229.

67 Por. „Visite de l'Administrateur de la Société des Batignolles”, 30 VI 1927, AD, CPC PL 1918-1940, 261, k. 199.

${ }^{68}$ Z. Landau, Pożyczki ulenowskie, „Najnowsze Dzieje Polski. Materiały i Studia z okresu 1914-1939" 1, 1958, s. 123-160.

${ }^{69}$ J. Laroche do A. Brianda, 16 XII 1927, AD, CPC PL 1918-1940, 237, k. 110-111.

70 „Projets de travaux de la Société des Batignolles à l'étranger”, 1 III 1928, AD, CPC PL 1918-1940, 231, k. 212-213; „Extrait du compte rendu d'un entretien du Directeur Politique avec les administrateurs de la Société de Constructions des Batignolles", 1 III 1928, AD, CPC PL 1918-1940, 263, k. 223-224.

71 „Visite de M.M. Lebert et Coin, administrateurs de la Société des Batignolles”, 13 X 1928, AD, CPC PL 1918-1940, 237, k. 146-147. 
Société des Construction des Batignolles, nie znalazła w archiwach firmy informacji o przyczynach niepowodzenia ${ }^{72}$. Można przypuszczać, że ponownie stały za nim trudności w pozyskaniu finansowania operacji.

Zanim jeszcze wybrzmiała propozycja Batignolles, sytuacja koncesjonariuszy z 1924 r. uległa zasadniczej zmianie. 7 czerwca 1927 r. zostali poinformowali, że polska Rada Ministrów zdecydowała się, bez konsultacji z parlamentem, odmówić im gwarancji finansowej. Jednocześnie zobowiązano ich do przedstawienia do 1 lipca 1927 r. projektu realizacji budowy bez gwarancji albo zrezygnowania z koncesji ${ }^{73}$. Wyjątkowo krótki termin wyznaczony po tak długim zwlekaniu francuskie firmy zinterpretowały słusznie jako próbę całkowitego zerwania z nimi współpracy $^{74}$. Notabene, w branżowym „Inżynierze Kolejowym” artykuły na temat połączenia Gdyni ze Śląskiem już od 1926 r. zupełnie pomijały istnienie koncesji.

Jak rozumieć te działania? Pozbawieni wsparcia ministra finansów i rynku paryskiego Francuzi nie mogli liczyć na finansowanie, a w konsekwencji na rozpoczęcie prac. Jednocześnie istnienie koncesji ograniczało działania polskiego rządu. Stąd dążenie do jej unieważnienia. Problem budowy magistrali był dla władz polskich tym bardziej palący, że strajk angielski w 1926 r. obnażył wyjątkowo niską przepustowość istniejących linii, które nie były w stanie obsłużyć zwiększonych przewozów ${ }^{75}$. Wraz z rosnącą presją na rozwój eksportu i poszukiwanie nowych rynków zbytu węgla stworzenie linii do Bałtyku okazało się jeszcze ważniejsze. Można się zresztą zastanawiać, jak przedstawiały się szanse na przeprowadzenie w parlamencie ustawy przyznającej pomoc koncesjonariuszom na niekorzystnych raczej dla Polski zasadach. Pytanie to jest zresztą równie zasadne wobec rządu Grabskiego w 1925 r., jak i gabinetu Aleksandra Skrzyńskiego.

W nowej sytuacji francuskie firmy zwróciły się o pomoc do swoich reprezentantów ${ }^{76}$, oskarżając rząd polski o niewywiązywanie się z zobowiązań. Powoływały się na wspomniany wyżej art. 15 porozumienia przedkoncesyjnego, zgodnie z którym minister kolei żelaznych zobowiązał się

72 A. Burnel, op. cit., s. 230-231.

73 „Note sur la concession de chemins de fer en Pologne dits «Chemins de fer houillers»", 10 VI 1927, AD, CPC PL 1918-1940, 263, k. 189.

${ }^{74} \mathrm{~W}$ późniejszej notatce pisano nawet, że było to równoznaczne z jednostronnym anulowaniem koncesji (Concession des Chemins de Fer Silésie-Varsovie-Baltique, Direction des Études de la Ligne Wieluń-Inowrocław do J. Laroche'a, 14 III 1928, AD, CPC PL 1918-1940, 263, k. 233).

75 B. Dopierała, Wokót polityki morskiej Drugiej Rzeczypospolitej. Studia historyczne, Poznań 1978, s. 264-265; M. Widernik, op. cit., s. 34.

${ }^{76}$ J. Tripier do A. Brianda, 1 IX 1927, AD, CPC PL 1918-1940, 263, k. 197, 200. 
zwrócić w sprawie gwarancji do parlamentu. Poseł Laroche interweniował, rozpoczynając kilkumiesięczny konflikt ${ }^{77}$.

Działania dyplomatyczne zdawały się przejściowo przynosić rezultaty. Minister komunikacji podjął rozmowy z koncesjonariuszami i obiecał zająć się zaproponowanym przez nich studium linii Śląsk-Gdynia. Intencje te potwierdził listem z 8 sierpnia 1927 r., zapowiadając powrót do rozmów we wrześniu ${ }^{78}$. Koncesjonariusze mogli to rozumieć jako otwarcie możliwości zmiany warunków czy też poszerzenia koncesji. W późniejszym omówieniu konfliktu wspominali, że polskie władze sugerowały możliwość przekazania im - jako kompensatę za oficjalne anulowanie pierwotnej koncesji - budowy linii bezpośrednio do Gdyni ${ }^{79}$. Nieco wcześniej, listem z 1 lipca 1927 r., polskie władze zaprosiły koncesjonariuszy na rozmowy na temat od dawna oczekiwanego dokumentu koncesyjnego, które miały rozpocząć się 1 stycznia 1928 r. ${ }^{80}$ Można zatem odrzucić tezę Mylène Mihout-Natar, że Francuzi zrezygnowali z koncesji już w czerwcu $1927 \mathrm{r}^{81}$

Dopiero po tej wymianie korespondencji urzędnicy z pałacu Brühla wysłali odpowiedź na notę Laroche'a. Jej duch wydawał się być sprzeczny z dość sprzyjającym stanowiskiem Ministerstwa Komunikacji w rozmowach $\mathrm{z}$ koncesjonariuszami ${ }^{82}$. Polacy pisali, że nie tylko nigdy nie zobowiązali się udzielić Francuzom gwarancji, ale też Ministerstwo Komunikacji nie mogło tego uczynić z racji zapisów ustawy o koncesjach.

Strona polska nie wróciła do rozmów w sprawie modyfikacji koncesji. W konsekwencji, przedstawiciele koncesjonariuszy nie stawili się na rozmowy dotyczące dokumentu koncesyjnego, nie chcąc swoim uczestnictwem zaakceptować stanu faktycznego ${ }^{83}$. Liczyli, że działając w ten sposób zablokują powstanie samego dokumentu, który zgodnie ustaleniami miały przygotować wspólnie polskie władze z koncesjonariuszami. Tymczasem, 8 stycznia 1928 r., polskie władze zaskoczyły ich przesłaniem

77 Nota werbalna AFW do MSZ, 23 VI 1927, AD, CPC PL 1918-1940, 263, k. 198-199v.

$78 \mathrm{Za}$ : „Note sur la concession de chemins de fer en Pologne dits «Chemins de fer houillers»", [luty 1928 r.], AD, CPC PL 1918-1940, 263, k. 214.

${ }^{79}$ Concession des Chemins de Fer Silésie-Varsovie-Baltique, Direction des Études de la Ligne Wieluń-Inowrocław do J. Laroche’a, 14 III 1928, AD, CPC PL 1918-1940, 263, k. 234.

80 J. Laroche do A. Brianda, 28 II 1928, AD, CPC PL 1918-1940, 263, k. 219-220v.

${ }^{81}$ M. Mihout-Natar, op. cit., s. 744; por. Ch. Laforest, „La stratégie française”, s. 182.

82 "Note "Concession de chemins de fer en Pologne» pour Monsieur Philippe Berthelot", 2 II 1928, AD, CPC PL 1918-1940, 263, k. 208.

83 Concession des Chemins de Fer Silésie-Varsovie-Baltique, Direction des Études de la Ligne Wieluń-Inowrocław do J. Laroche'a, 14 III 1928, AD, CPC PL 1918-1940, 263, k. 236, k. 233. 
stworzonego przez siebie dokumentu ${ }^{84}$, który nie zawierał klauzuli gwarancyjnej i dotyczył tylko pierwotnie ustalonych linii.

Według Francuzów jego forma i treść czyniły ze wstępnego porozumienia, podpisanego przed nadaniem koncesji, „świstek papieru” ${ }^{\text {"5 }}$. Po pierwsze, został przygotowany bez porozumienia $\mathrm{z}$ francuskimi firmami. Po drugie, obligował koncesjonariuszy do złożenia w ciągu dwóch miesięcy depozytu w Warszawie w wysokości 89 mln złotych oraz przedstawienia gwarancji, że dysponują kwotą $900 \mathrm{mln}$ złotych, konieczną według Ministerstwa Komunikacji do sfinansowania budowy. Po trzecie, polskie władze zażądały od Francuzów przedstawienia w terminie czterech tygodni (do 15 lutego 1928 r.) ostatecznych projektów technicznych i ogólnego kosztorysu projektu ${ }^{86}$.

Francuzi słusznie widzieli w tym chęć wymuszenia zakończenia koncesji. Potwierdziło to wydanie 7 lutego 1928 r. przez prezydenta Ignacego Mościckiego rozporządzenia regulującego budowę kolei na trasie Herby Nowe-Inowrocław ${ }^{87}$, faktycznie powielającej najważniejszą część pierwotnej koncesji (choć, jak wspomniano wyżej, biegła ona prawym, a nie lewym brzegiem Warty). Koncesjonariusze pisali do francuskich dyplomatów: „sytuacja stała się wyjątkowo niejasna. Jasna wydaje się tylko wola rządu ignorowania swoich wcześniejszych zobowiązań i pozbawiania nas nabytych praw" ${ }^{88}$. Interwencja Laroche'a nie przyniosła rezultatów ${ }^{89}$. Koncesjonariusze oficjalnie deklarowali, że dysponują środkami koniecznymi do rozpoczęcia budowy ${ }^{90}$ i protestowali przeciw polskim

${ }^{84}$ Jak wspomniałem wyżej, koncesjonariusz był zobowiązany na swój koszt wydrukować dokument koncesyjny w „Monitorze Polskim”. Nie odnalazłem tego dokumentu w „Monitorze” ani w styczniu, ani w lutym 1928 r. Zapewne wobec braku zgody Francuzów na zapisy dokumentu nie został on nigdy opublikowany. Aby upewnić się, czy „dokument koncesyjny” (z koncesji) jest tożsamy z cahier des charges (z francuskiej korespondencji) i „planem generalnym” (z ustawy), przeprowadziłem również - bez rezultatu - kwerendę „Monitora” za okres 1 XII 1924 - 31 I 1925, czyli bezpośrednio po przyznaniu koncesji.

85 J. Laroche do A. Brianda, 28 II 1928, AD, CPC PL 1918-1940, 263, k. 220v.

${ }^{86}$ Odtworzenie specyfikacji na podstawie francuskiego protestu: J. Laroche do A. Zaleskiego, 12 II 1928, AD, CPC PL 1918-1940, 263, k. 203-205; „Note sur la concession de chemins de fer en Pologne dits «Chemins de fer houillers»", ibidem, k. 210-216.

${ }^{87}$ M. Widernik, op. cit., s. 38; Rozporzadzenie Prezydenta Rzeczypospolitej z dnia 7 lutego 1928 r. w sprawie budowy kolei Herby-Inowrocław, Dz. U. 1928, nr 16, poz. 123.

${ }^{88}$ Concession des Chemins de Fer Silésie-Varsovie-Baltique, Direction des Études de la Ligne Wieluń-Inowrocław do J. Laroche'a, 14 III 1928, AD, CPC PL 1918-1940, 263, k. 235.

${ }^{89}$ Nota werbalna J. Laroche'a do A. Zaleskiego, 2 III 1928, AD, CPC PL 1918-1940, 263, k. 225-226; J. Laroche do A. Brianda, 2 III 1928, ibidem, k. 227-228.

90 Nota J. Laroche'a do A. Zaleskiego, 12 II 1928, AD, CPC PL 1918-1940, 263, k. 204. 
planom. Faktycznie dążyli jednak już tylko do odzyskania poniesionych kosztów i przyznania w formie kompensacji za utratę koncesji kontraktu na część prac przy budowie nowej linii ${ }^{91}$. Sprawa pierwszej koncesji zakończyła się zatem faktycznie na początku 1928 r., choć jeszcze dwa lata później Schneider i Société Génerale d'Entreprises nie mogły uzyskać odszkodowania za wykonane prace ${ }^{92}$.

W dalszych rozmowach polsko-francuskich, które zakończyły się przyznaniem w 1931 r. drugiej koncesji na budowę całej magistrali węglowej (a nie jedynie jej środkowego odcinka), uczestniczył już tylko Schneider wraz z Banque de Pays du Nord. Bank ten wcześniej brał udział m.in. we francuskiej pożyczce kolejowej dla carskiej Rosji ${ }^{93}$. Na liście udziałowców powstałej w wyniku tej koncesji francuskiej spółki akcyjnej Compagnie Franco-Polonaise de Chemins de Fer (Francusko-Polskie Towarzystwo Kolejowe) obok tych firm widniało jednak m.in. również Société Génerale d'Entreprises ${ }^{94}$. Tak Polacy, jak i Francuzi traktowali zatem pierwszą koncesję jako niebyłą. W polskich środowiskach kolejowych najlepiej oddał to artykuł komentujący udzielenie koncesji w 1931 r. pod znamiennym tytułem Pierwsza koncesja kolejowa w Polsce ${ }^{95}$.

\section{Strony negocjacji i interpretacja przebiegu rozmów}

Negocjacje na temat pierwszej koncesji prowadziły prywatne firmy francuskie (i polskie Tri). Jak wspomniałem, budowa kolei za granicą stanowiła we Francji domenę sektora robót publicznych, który w okresie międzywojennym przeżywał kryzys, nie radząc sobie z konkurencją Amerykanów i Anglików. Częściowo wynikało to z rosnącej izolacji rynków międzynarodowych po I wojnie światowej, częściowo zaś z trudnej sytuacji samej Francji, w której firmy miały problem z dostosowaniem się do rosnącej technologicznej przewagi Anglosasów. Nadzieją dla

91 Concession des Chemins de Fer Silésie-Varsovie-Baltique, Direction des Études de la Ligne Wieluń-Inowrocław do J. Laroche’a, 14 III 1928, AD, CPC PL 1918-1940, 263, k. 239; J. Laroche do A. Brianda, 22 III 1928, ibidem, k. 229-229v.

${ }_{92}$ Chemins de fer en Pologne, 5 VI 1930, AD, CPC PL 1918-1940, 408, k. 29.

93 B.V. Anan'ich, V.I. Bovykin, Foreign Banks and Foreign Investment in Russia, w: International Banking 1870-1914, red. R. Cameron, V.I. Bovykin, New York-Oxford 1991, s. 264.

94 „Compagnie Franco-Polonaise de Chemins de Fer”, 1 VI 1934, AD, CPC PL 19181940, 409, k. 131-134.

95 S. Sztolcman, Pierwsza koncesja kolejowa w Polsce, „Inżynier Kolejowy” 8, 1931, 7, s. $217-219$. 
firm francuskich (poza koloniami) były nowe kraje Europy Środkowej i Wschodniej, w których polityczna pozycja Francji umożliwiała przedsiębiorcom znad Sekwany łatwiejszą ekspansję ${ }^{96}$. Najważniejszym z tych rynków była Polska. Zgodnie z obliczeniami Dominque’a Barjota, w latach 1919-1929 budowy w Polsce stanowiły 26 proc. wszystkich inwestycji zrealizowanych za granicą przez 15 największych firm sektora; w okresie 1929-1939 odsetek ten wzrósł aż do 38 proc. ${ }^{97} \mathrm{Na}$ udział ten składały się głównie dwie inwestycje: port w Gdyni oraz właśnie magistrala węglowa. Opisana sytuacja tłumaczy znaczenie pierwszej koncesji dla firm francuskich, a także fakt niemal płynnego przejścia przez nie do negocjacji, które doprowadzily do nadania drugiej koncesji, mimo fatalnego potraktowania przez Polaków w latach 1927-1928.

Firmy francuskie wydawały się dobrze dobrane do projektu. Założone w 1908 r. Société Générale d'Entreprises (obecnie Vinci SA) było jedną z najważniejszych firm sektora. Doświadczenie przedsiębiorstwa potwierdzały udziały w systemie kolei podmiejskiej Lille (RoubaixTourcoing) i w Énergie Électrique du Nord, ważnej francuskiej firmie energetycznej, a także budowa rozdzielni elektrycznej w podparyskim Gennevilliers i innej linii kolejowej ${ }^{98}$. Grupa przemysłowa Schneider et $C^{\text {ie }}$, względnie Schneider-Creusot, jeden z najpoważniejszych producentów uzbrojenia w Europie, posiadała wówczas istotne udziały w Europie Środkowej. W 1920 r. firma ta wraz z Banque de l'Union Parisienne utworzyła holding w celu „kontroli inwestycji w bankowość i przemysł poczynionych przez Eugène'a Schneidera wkrótce po I wojnie światowej na ruinach imperium austro-węgierskiego" 99 . W Polsce Schneider zaangażował się w przedsiębiorstwa górnicze i hutnicze, w Czechosłowacji był udziałowcem Skody oraz kopalni i hut na Śląsku Cieszyńskim. W 1924 r. firma stała się też częścią konsorcjum polsko-francuskiego, któremu powierzono budowę portu w Gdyni. Wszystkie te przedsięwzięcia mogły zyskać na skróceniu połączenia Śląska z Bałtykiem, omijającego terytorium Niemiec.

W dokumentach z lat trzydziestych pierwsza koncesja nazywana jest niekiedy od nazwisk negocjatorów koncesją Weyl-Natanson ${ }^{100}$. Pierwszym

96 G.-H. Soutou, L'impérialisme du pauvre.

97 D. Barjot, La grande entreprise, s. 349.

98 D. Barjot, L'analyse comptable. Un instrument pour l'histoire des entreprises. La Société Générale d'Entreprises 1908-1945, „Histoire, économie et société” 1, 1982, 1, s. 155.

${ }_{99} \mathrm{C}$. Beaud, Une multinationale française au lendemain de la Première Guerre mondiale. Schneider et l'Union Européenne Industrielle et Financière, „Histoire, économie et société” 2, 1983, 4, s. 625.

100 J. Laroche do A. Brianda, 3 VI 1930, AD, CPC PL 1918-1940, 408, k. 21. 
z nich był pułkownik Ernest Weyl, który wielokrotnie reprezentował Schneidera w Europie Środkowej i Wschodniej ${ }^{101}$, a jednocześnie zasiadał w Radzie Dyrektorów Société Générale d'Entreprises ${ }^{102}$. Na początku lat dwudziestych był też przedstawicielem interesów francuskich w negocjacjach z Niemcami na Górnym Śląsku, konkurując wówczas z polskim projektem Artura Benisa ${ }^{103}$. Drugim reprezentantem koncesjonariuszy był znany wydawca Tadeusz Natanson, z francuskiej gałęzi rodu, również związany z Société Générale d'Entreprises.

Kolejnym czynnikiem pozarządowym we Francji, który miał wpływ na losy koncesji, były firmy sektora finansowego. Nie dotarłem do szczegółowych dokumentów opisujących ich reakcje na próby pozyskania finansowania przez Schneidera i Société Générale d'Entreprises. Wiadomo, że na przełomie 1924 i 1925 r. koncesjonariusze spotkali się z odmową emisji polskiej pożyczki. Zapewne kluczowe znaczenie miała obawa przed angażowaniem się w Polsce: Francuzi nie wierzyli w powodzenie reform Grabskiego i stabilność złotego ${ }^{104}$, mieli też wątpliwości co do pozycji Polski w Europie ${ }^{105}$. Jak pisał Zbigniew Landau, „największy zysk nie mógł skłonić zagranicznych kapitalistów do podejmowania inwestycji kapitałowych w kraju, co do którego dalszych losów politycznych i gospodarczych istniały jakiekolwiek obawy. [--] Inwestorzy zagraniczni mieli jeszcze świeżo w pamięci konsekwencje rewolucji, która dokonała się w Rosji i spowodowała utratę miliardowych wierzytelności"106.

Niechęć sfer finansowych do angażowania się w polskie projekty rządowe po I wojnie światowej była stałym elementem negocjacji dotyczących francuskich inwestycji. Właściciele kapitału woleli przejmować udziały już istniejących firm o gwarantowanych dochodach, niż ryzykować utraty wkładów w niepewnych przedsięwzięciach. Mimo to, pewne inicjatywy zostały jednak skutecznie przeprowadzone. Przykładem może być Bank Śląski SA, powstały po długich negocjacjach w 1922 r., koncesja na budowę portu w Gdyni przyznana dwa lata później czy druga koncesja kolejowa z 1931 r. Wspólnym punktem wszystkich trzech przedsięwzięć było silne zaangażowanie władz francuskich, które potrafiły nie tylko

101 G.-H. Soutou, La politique économique de la France en Pologne (1920-1924), „Revue historique" 251, 1974, 1, s. 97.

102 R. Poincaré do H.A. de Panafieu, 12 V 1924, AD, CPC PL 1918-1940, 263, k. 103-104.

103 Por. M. Mihout-Natar, op. cit., s. 122-141; A.M. Cienciała, T. Komarnicki, From Versailles to Locarno. Keys to Polish Foreign Policy, 1919-25, Lawrence 1984, s. 103.

104 M. Pasztor, Francuskie opinie o polityce skarbowej i walutowej rzadu Władysława Grabskiego (1923-1925), „Mazowieckie Studia Humanistyczne” 5, 1999, 1, s. 157-165.

105 Z. Landau, Polskie zagraniczne pożyczki, s. 202-204.

106 Z. Landau, Plan stabilizacyjny, s. 89, 118-120. 
wywrzeć wpływ na francuski rynek finansowy, ale też wymusić na Polsce przyjęcie korzystnych dla niego rozwiązań. Taki model aktywnej partycypacji władz był widoczny szczególnie w sprawach, które Francuzi uznali za strategiczne ${ }^{107}$.

W przypadku pierwszej koncesji kolejowej negocjacje prowadzone były z niewielkim jedynie udziałem dyplomatów w Warszawie i mniejszym jeszcze władz w Paryżu. Za brakiem pomocy przedstawicieli rządu w rozmowach stała zapewne wyraźna odmowa udzielenia wsparcia przez Ministerstwo Finansów, która w znacznym stopniu ograniczała pole działania MAÉ. Jak wspomniałem, decyzja ta, podjęta przez rząd Raymonda Poincarégo, została podtrzymana przez kolejne gabinety. W Trzeciej Republice premier musiał niekiedy ugiąć się przed wolą królewskiego Luwru, w którym siedzibę miał resort finansów.

W konsekwencji, władze francuskie zaoferowały inwestorom jedynie porady, poparcie w Polsce oraz interwencje w konkretnych sprawach ${ }^{108}$. W kryzysowej sytuacji 1928 r. Laroche zapewniał Natansona, że dołoży wszelkich starań, aby rozwiązać problemy koncesjonariuszy. Dodawał jednak, krytykując nadmierną zależność negocjatorów od działań dyplomatów, że interwencje ambasady nie mogą zastępować działań zainteresowanych stron, a powinny jedynie je wspierać109. Z postawą Francuzów, którą podpowiadali im specjalizujący się w rynku polskim prawnicy, można wiązać przekonanie, że losy koncesji stały się problemem politycznym, związanym ze zmianą polskich władz po zamachu majowym ${ }^{110}$, wymagającym w konsekwencji również politycznego rozwiązania.

Innymi słowy, za niepowodzeniem pierwszej koncesji kolejowej we Francji stała niemożność zmobilizowania kapitałów na emisję obligacji, a przez to sfinansowanie budowy. Potwierdza to podstawową interpretację obecną w literaturze. Jednocześnie jednak, jak pokazałem, zaangażowanie francuskich władz było w stanie wielokrotnie pokonywać nieufność rynku w innych przypadkach. Nie doszło do tego w przypadku pierwszej koncesji z powodu braku zgody Ministerstwa Finansów. Każe to widzieć porażkę rozmów z Polską jako część szerszych problemów gospodarczych Francji, które podkopywały możliwość prowadzenia przez nią dyplomacji gospodarczej.

107 Por. Instrukcja dla posła Chłapowskiego, [1924], AAN, MSZ, 3839, k. 5-11. O takim stanowisku władz francuskich piszę w: J. Łazor, „Broń dyplomatyczna pierwszej rangi”? Powstanie polsko-francuskiego Banku Śląskiego SA, RDSG 81, 2020, s. 289-320; idem, Kto ma budować Gdynię?

108 J. Tripier do A. Brianda, 1 IX 1927, AD, CPC PL 1918-1940, 263, k. 200.

109 [J. Laroche] do T. Natansona, 18 II 1928, AD, CPC PL 1918-1940, 263, k. 207.

110 A. Briand do J. Laroche'a, 20 II 1928, AD, CPC PL 1918-1940, 263, k. 217-218. 
Z racji ograniczonego zachowania polskich źródeł, znacznie mniej można powiedzieć na temat stanowiska Warszawy. Najważniejszym podmiotem prowadzącym początkowe rozmowy z Francuzami było Ministerstwo Komunikacji (a wcześniej Kolei Żelaznych i Kolei), na późniejsze zaś skargi odpowiadało Ministerstwo Spraw Zagranicznych. W 1924 r. w rozmowach uczestniczył również premier Władysław Grabski. Francuzi wspominają o różnicach zdań między polskimi podmiotami, zwłaszcza o agresywnej postawie Grabskiego i tonującej ministra kolei Kazimierza Tyszki ${ }^{111}$. Trudno na tej podstawie wyciągać szersze wnioski, choć należy przyznać, że sceptyczna postawa premiera znalazła potwierdzenie w niemożności pozyskania finansowania przez Francuzów. Z racji braku źródeł nie wiem nic o polityce gabinetu Aleksandra Skrzyńskiego wobec koncesji.

Nawet jednak podejście Grabskiego okazało się niezwykle stonowane w porównaniu do działań z 1927 i 1928 r. Kiedy Polacy zdecydowali się sami zbudować kolej na trasie Kalety-Podzamcze, to mimo wielkiej wagi projektu podjęli wpierw rozmowy z Francuzami, czując się związani koncesją. Gdy trzy lata później Francuzi starali się blokować działania Polaków, ci przyjęli taktykę faktów dokonanych, ignorując zapisy koncesji. W odbiorze koncesjonariuszy był do dowód, że nowe władze nie czuły się związane postanowieniami sprzed zamachu majowego i dążyły do ich zmiany.

O stosunku obozu sanacji do kapitału zagranicznego szczegółowo pisał Zbigniew Landau. Dowodził on, że bezpośrednio po zamachu majowym nowe władze niemal bezrefleksyjnie szły na rękę inwestorom, kontynuując z sukcesem wszystkie trwające wówczas ważne negocjacje. „Świadczy o tym nie tylko akceptowanie umów na warunkach bardzo ciężkich [--], bez zapewnienia równych korzyści obu stronom [--], z koniecznością zapłacenia sum przekraczających faktycznie zobowiązania państwa [--], ale również i szybkość, z jaką wszystkie kwestie związane z kapitałami obcymi były załatwiane"112. W dalszej kolejności celem stało się uzyskanie wielkiej pożyczki, która miała uczynić z Polski część szerszego międzynarodowego rynku finansowego. Starano się wówczas nie brać pod uwagę ofert o niewielkiej wartości, a także nie powielać błędów doby Grabskiego i nie wiązać państwa równie niekorzystnymi pożyczkami jak tytoniowa. Jednoczesne zwiększenie zainteresowania kapitału zagranicznego Polską pod koniec 1926 r. zdawało się sugerować możliwość prowadzenia bardziej intencjonalnej polityki1 ${ }^{113}$.

111 A.G. de Gontaut-Biron do E. Herriota, 20 VI 1924, AD, CPC PL 1918-1940, 263, k. $122 \mathrm{v}$.

112 Z. Landau, Plan stabilizacyjny, s. 59.

113 Ibidem, s. 63-88. 
Działania wobec koncesjonariuszy jawią się jako taka właśnie forma bardziej intencjonalnej polityki, prowadzonej wobec szczególnie mało produktywnej działalności obcego kapitału. I choć musiały one w pewnym stopniu zmniejszyć zaufanie inwestorów do polskiego rynku, w przyszłości okazały się przydatne: gdy Schneider negocjował przyznanie drugiej koncesji, Francuzi pewnych ofert nawet nie rozważali, traktując polski nacjonalizm gospodarczy jako oczywistośćc14.

$\mathrm{Na}$ pozycję negocjacyjną Polaków wpływ miała sytuacja gospodarcza kraju. Rozmowy na temat koncesji sięgają końca 1923 r. - okresu hiperinflacji, kiedy możliwość pozyskania kapitału na ważną inwestycję była szczególnie cenna. Grabski negocjował z Francuzami w trakcie wprowadzania reform, które zmuszony był przeprowadzić w oparciu o krajowe zasoby. Sytuacja w latach 1927-1928 była już inna. W kraju panowała dobra koniunktura gospodarcza, a pożyczka stabilizacyjna pokazała, że Polacy mogli liczyć na poważne oferty od zagranicznych inwestorów. Z tej perspektywy nieproduktywna koncesja musiała jawić się jako niepotrzebne ograniczenie, zwłaszcza wobec ochłodzenia stosunków z Francją.

Warto też zastanowić się nad kwestią gwarancji, której udzielenia odmówili koncesjonariuszom Polacy, co z kolei stało za opiniami Francuzów o niemożności realizacji koncesji. Choć gwarancja była dla inwestorów istotna, stanowiąc potwierdzenie minimalnego poziomu zysku, wobec nieufności inwestorów nie stanowiła ona warunku wystarczającego dla przeprowadzenia emisji pożyczki. Dlatego polska gwarancja, czy w 1925, czy w 1927 r., nie mogła zmienić nastawienia paryskich inwestorów bez dodatkowych działań ze strony władz Trzeciej Republiki.

Przebadane dokumenty nie pozwalają na szersze rozważania na temat znaczenia „Tri” Towarzystwa Robót Inżynierskich. Na podstawie materiałów francuskich trudno przypisać mu większą rolę niż jedynie pośrednika między władzami a inwestorami znad Sekwany. Jednocześnie jednak to ta firma odpowiedzialna była za utworzenie konsorcjum i część negocjacji prowadzących do ustalenia wstępnych warunków koncesji. Ta istotna rola nie znajduje kontynuacji w późniejszych dokumentach. W czasie konfliktu z lat 1927-1928, Tri nie pojawia się we francuskiej korespondencji z Ministerstwem Komunikacji. Trudno się dziwić. Równolegle firma ta zaczęła realizację części robót na odcinkach magistrali węglowej budowanych przez Polaków. Umowę dotyczącą budowy odcinka Osowa-Kack Wielki Tri podpisało 3 września 1927 r., Kack Wielki-Gdynia - 28 lutego 1928, a Kozuby-Otok - 25 września 1928 r. ${ }^{115}$ Faktycznie

114 J. Laroche do A. Brianda, 3 VI 1930, AD, CPC PL 1918-1940, 408, k. 21.

115 G. Kotlarz, H. Dąbrowski, E. Wieczorek, op. cit., s. 48. 
zatem firma, jako pierwszy z koncesjonariuszy, pogodziła się z nową sytuacją. Na początku lat trzydziestych drogą tą poszli też Francuzi.

\section{Zakończenie}

Najprostsze wytłumaczenie niepowodzenia koncesji dla polsko-francuskiego konsorcjum z 1924 r. każe je łączyć z niepodjęciem przez koncesjonariuszy prac, które z kolei wynikało z niemożności pozyskania finansowania na rynku paryskim. Za porażką tą stały jednak problemy głębsze niż ostrożność prywatnych banków Trzeciej Republiki. Kluczowym czynnikiem były tu decyzje dwóch rządów. Zdecydowana postawa ministra finansów przesądziła o odmowie francuskich władz wsparcia koncesjonariuszy w staraniach o pozyskanie finansowania. Dla porównania, paryski rząd w zdecydowany sposób poparł analogiczne działania innej grupy francuskich koncesjonariuszy zabiegających o koncesję na budowę portu w Gdyni, a następnie finansowanie jej realizacji. Brak analogicznej pomocy z pewnością przyczynił się do miernych rezultatów starań Schneidera i Société Générale d'Entreprises. Budowa portu została w połowie lat dwudziestych uznana w Paryżu za ważniejszą inwestycję od linii kolejowej.

Dalsza historia pierwszej koncesji jest z kolei ilustracją zmiany polskiej pozycji. Jeszcze w 1925 r. Polacy planowaną modyfikację układu z koncesjonariuszami poprzedzili kurtuazyjnymi negocjacjami, których wyniki były korzystne dla obydwu stron. Po 1926 r. umowa z Francuzami - niegwarantująca szybkiego wybudowania linii - zaczęła polskim rządom wadzić. W konsekwencji, najpierw odmówiły one koncesjonariuszom gwarancji finansowej, a następnie postawiły ich przed faktami dokonanymi. Działania Polaków należy interpretować jako coraz bardziej forsowne próby pozbycia się pierwszej koncesji, zakończone w 1928 r. powodzeniem.

Dla sukcesu ważnych inwestycji francuskich w Polsce istotne znaczenie miało stanowisko władz państwowych w obydwu krajach. Bez zaangażowania rządu francuskiego trudno było sobie wyobrazić pozyskanie finansowania oraz skłonienie Polaków do ustępstw gwarantujących zainteresowanie inwestorów. Zła wola po stronie polskiej tworzyła z kolei trudne do przekroczenia bariery instytucjonalne. Mimo asymetrii sił między Paryżem i Warszawą, wykorzystywanej często przez francuskich dyplomatów i ludzi biznesu, władze nad Wisłą dysponowały sporymi możliwościami manewru negocjacyjnego, a ich zdecydowana postawa umożliwiała wywarcie wyraźnego wpływu na Francuzów.

Widzę kilka możliwości pogłębienia niniejszych badań. Pierwszą byłoby dokonanie analogicznej analizy dla kilku innych inwestycji 
francuskich w Polsce, zarówno zakończonych sukcesem, jak i porażką. Powinno to pozwolić na określenie, na ile wnioski wyniesione z badania konkretnego przypadku pierwszej koncesji da się rozciągnąć na szerszy problem działania kapitału francuskiego w Drugiej Rzeczypospolitej. W szczególności interesujące byłoby porównanie negocjacji prowadzących do przyznania drugiej koncesji na budowę kolei. Po drugie, nowe odpowiedzi na pytania poruszane w niniejszym tekście może dać wykorzystanie kolejnych źródeł: materiałów zostawionych przez firmy francuskie zaangażowane w negocjacje oraz ewentualnie dokumentów polskich, zlokalizowanych $\mathrm{w}$ archiwach lokalnych. Po trzecie, przedstawione badania należy wpisać w międzywojenną dyskusję na temat kształtu polskiej kolei i państwowych inwestycji infrastrukturalnych.

\section{Streszczenie}

W 1924 r. Polska przyznała konsorcjum polsko-francuskiemu koncesję na budowę sieci kolejowej, zawierającej część przyszłej magistrali węglowej. Po kłopotach $\mathrm{z}$ uzyskaniem przez francuskie firmy finansowania w Paryżu, Polacy najpierw zmodyfikowali koncesję, a w 1928 r. faktycznie ją anulowali. Za porażką przedsięwzięcia stały nie tylko trudności z emisją pożyczki we Francji, lecz również brak wsparcia ze strony francuskich władz. Sytuacja ta wynikała z kłopotów gospodarczych samej Francji, które okazały się ważniejsze od politycznego znaczenia zaangażowania się w budowę polskich kolei. Losy koncesji wpisują się też w szerszą zmianę podejścia do kapitału zagranicznego i samej Francji po przewrocie majowym. Kiedy w 1925 r. Polacy chcieli zmodyfikować koncesję, decyzje poprzedzili negocjacjami z Francuzami, których rezultaty były korzystne dla obydwu stron. W latach 1927-1928 władze w Warszawie stawiały swoich rozmówców przed faktami dokonanymi i ignorowały protesty dyplomatyczne. Casus koncesji pokazuje, że choć działania Francuzów w Polsce opisywane są w literaturze jako imperialistyczne, to nawet w ramach asymetrycznych relacji polsko-francuskich słabsza strona miała manewr negocjacyjny, a powodzenie przedsięwzięć francuskich firm niekiedy zależało od decyzji Warszawy.

\section{The First Franco-Polish Railway Concession of 1924. A Contribution to the Financial and Economic Relations between Poland and France after the First World War}

In 1924, Poland granted a Polish-French consortium a concession to construct a railway network that formed part of the future coal mainline. Since French companies struggled to obtain financing in Paris, the Poles first modified the concession, and in 1928 cancelled it. Behind the project's failure were not only 
difficulties with securing loans in France but also a lack of support from the French authorities. This situation resulted from France's economic troubles, which proved more important than the political significance of its involvement in constructing the railway in Poland. The fate of the concession is also part of a broader change in the Polish government's approach to foreign capital and France itself after the 1926 May Coup. When, in 1925, Poles wanted to modify the concession, they consulted the French before taking a decision, the results of which were beneficial to both parties. In 1927-28, the authorities in Warsaw presented their interlocutors with faits accomplis and ignored diplomatic protests. The case of the concession shows that, although the actions of the French in Poland are described in the literature as imperialist, even within the framework of asymmetrical Polish-French relations, the weaker party (Poland) had room for manoeuvre, and the success of the ventures of French companies on occasion depended on decisions taken in Warsaw.

\section{Bibliografia}

\section{Opracowania}

Anan'ich Boris V., Bovykin Valeriǔ I., Foreign Banks and Foreign Investment in Russia, w: International Banking 1870-1914, red. Rondo Cameron, Valeriǐ I. Bovykin, Oxford University Press, New York-Oxford 1991, s. 253-290.

D’Angio Agnès, Schneider et Cie et la naissance de l'ingénierie. Des pratiques internes à l'aventure internationale 1836-1949, CNRS Editions, Paris 2000.

Barjot Dominque, La grande entreprise française de travaux publics (1883-1974), Economica, Paris 2006.

Barjot Dominque, L'analyse comptable. Un instrument pour l'histoire des entreprises. La Société Générale d'Entreprises 1908-1945, „Histoire, économie et société” 1, 1982, 1 , s. $145-168$.

Beaud Claude, Une multinationale française au lendemain de la Première Guerre mondiale. Schneider et l'Union Européenne Industrielle et Financière, „Histoire, économie et société" 2, 1983, 4, s. 625-645.

Błahut Karol J., Polsko-niemieckie stosunki gospodarcze w latach 1919-1939, Ossolineum, Wrocław 1975.

Bułhak Henryk, Polska - Francja. Z dziejów sojuszu 1922-1939, cz. 1: 1922-1932, Wydawnictwa Fundacji „Historia pro Futuro”, Warszawa 1993.

Burnel Anne, La société de construction des Batignolles de 1914 à 1939. Histoire d'un déclin, Droz, Genève 1995.

Cienciała Anna M., Komarnicki Tytus, From Versailles to Locarno. Keys to Polish Foreign Policy, 1919-25, Kansas University Press, Lawrence 1984.

Dopierała Bogdan, Wokół polityki morskiej Drugiej Rzeczypospolitej. Studia historyczne, Wydawnictwo Poznańskie, Poznań 1978.

Kapitał państwowy w spółkach prawa handlowego u schyłku Drugiej Rzeczypospolitej. Szczegótowe sprawozdanie z działalności przedsiębiorstw o kapitale mieszanym za rok 
1937 wzgl. 1937/1938, red. Jerzy Gołębiowski, Wydawnictwo Naukowe Akademii Pedagogicznej, Kraków 2004.

Kotlarz Grzegorz, Dąbrowski Henryk, Wieczorek Edward, Magistrala węglowa. Najciekawsze linie kolejowe Polski, Eurosprinter, Rybnik 2017.

Laforest Christopher, Kulisy zrzeczenia się przez Polskę czwartej raty pożyczki francuskiej w 1925 r., „Dzieje Najnowsze” 31, 1999, 3, s. 91-99.

Laforest Christopher, „La stratégie française et la Pologne (1919-1939). Aspects économiques et implications politiques", praca doktorska obroniona w Université Paris 1 Panthéon-Sorbonne, Paris 2001.

Laforest Christopher, La stratégie française et la Pologne (1919-1939). Aspects économiques et implications politiques, „Histoire, économie et société” 22, 2003, 3, s. 395-411.

Landau Zbigniew, Plan stabilizacyjny 1927-1930. Geneza, założenia, wyniki, Książka i Wiedza, Warszawa 1963.

Landau Zbigniew, Polskie zagraniczne pożyczki państwowe 1918-1926, Książka i Wiedza, Warszawa 1961.

Landau Zbigniew, Pożyczki ulenowskie, „Najnowsze Dzieje Polski. Materiały i Studia z okresu 1914-1939" 1, 1958, s. 123-160.

Landau Zbigniew, Tomaszewski Jerzy, Anonimowi władcy. Z dziejów kapitału obcego w Polsce (1918-1939), Wiedza Powszechna, Warszawa 1968.

Landau Zbigniew, Tomaszewski Jerzy, Gospodarka Polski międzywojennej 1918-1939, t. 1: W dobie inflacji 1918-1923, Książka i Wiedza, Warszawa 1967.

Landau Zbigniew, Tomaszewski Jerzy, Gospodarka Polski międzywojennej 1918-1939, t. 2: Od Grabskiego do Piłsudskiego. Okres kryzysu poinflacyjnego i ożywienia koniunktury 1924-1929, Książka i Wiedza, Warszawa 1971.

Łazor Jerzy, „Broń dyplomatyczna pierwszej rangi”? Powstanie polsko-francuskiego Banku Śląskiego SA, „Roczniki Dziejów Społecznych i Gospodarczych” 81, 2020, s. 289-320.

Łazor Jerzy, Kapitat francuski w Polsce międzywojennej. Stan badań i postulaty badawcze, „UR Journal of Humanities and Social Sciences” 4, 2019, 1(10), s. 29-52.

Łazor Jerzy, Kto ma budować Gdynię? Wpływ władz w Paryżu na kształt konsorcjum francusko-polskiego, „Dzieje Najnowsze” [w druku].

Mouré Kenneth, Managing the Franc Poincaré. Economic Understanding and Political Constraint in French Monetary Policy, 1928-1936, Cambridge University Press, Cambridge 1991.

Mihout-Natar Mylène, „L'intervention des capitaux français dans la Pologne de la Seconde République (1918-1939). Contribution à l'histoire de l'impérialisme économique français en Europe centrale", praca doktorska obroniona w Université Charles de Gaulle - Lille III, Lille 2002.

Pasztor Maria, Francuskie opinie o polityce skarbowej i walutowej rządu Władysława Grabskiego (1923-1925), „Mazowieckie Studia Humanistyczne” 5, 1999, 1, s. 157-165.

Soutou Georges-Henri, L'Alliance franco-polonaise (1925-1933) ou comment s'en débarrasser, „Revue d'histoire diplomatique” 1981, 2, 3, 4, s. 295-348.

Soutou Georges-Henri, L'impérialisme du pauvre. La politique économique du gouvernement français en Europe Centrale et Orientale de 1918 à 1929. Essai d'interprétation, „Relations internationales” 3, 1976, 7, s. 219-239.

Soutou Georges-Henri, La politique économique de la France en Pologne (1920-1924), „Revue historique” 251, 1974, 1, s. 85-116. 
Wandycz Piotr S., The Twilight of French Eastern Alliances, 1926-1936. French-Czechoslovak-Polish Relations from Locarno to the Remilitarization of the Rhineland, Princeton University Press, Princeton 1988.

Widernik Mieczysław, Magistrala węglowa Ślask-Gdynia i jej znaczenie w okresie międzywojennym, „Zapiski Historyczne” 49, 1984, 2, s. 31-53.

Biogram: Dr Jerzy Łazor jest adiunktem w Katedrze Historii Gospodarczej i Społecznej Szkoły Głównej Handlowej w Warszawie. Specjalizuje się w historii okresu międzywojennego i międzynarodowych stosunkach gospodarczych Drugiej Rzeczypospolitej; kontakt: jlazor@sgh.waw.pl.

Author: Jerzy Łazor, PhD, assistant professor in the Department of Economic and Social History in the Warsaw School of Economics. He specializes in the history of the interwar period and the international economic relations of the Second Republic of Poland; contact: jlazor@sgh.waw.pl. 